\title{
Effect of Nitrogen Content of Beardless Wheatgrass on Yield Response to Nitrogen Fertilization ${ }^{1}$
}

\author{
J. L. MASON AND J. E. MILTIMORE \\ Canada Agriculture, Research Station, Summerland, B.C.
}

Notable increases in the yield of range grass have been obtained from nitrogen fertilization in the Western region of North America (Mader, 1957; Mason and Miltimore, 1959; Rogler and Lorenz, 1957). However, little is known about the relationship of the nitrogen content of range grasses and their yield response to nitrogen fertilization. Knowledge concerning this relationship could be used in assessing the yield response which might be expected from fertilizing given areas of range land. It would be particularly useful since soil tests for available nitrogen are known to be not very reliable. This paper presents data on the relation of nitrogen content of range grass to yield.

\section{Materials and Methods}

The experimental work is divided into two sections. The first is a detailed field plot experiment to determine the basic relationship of nitrogen content to yield of range grass. The second is a series of 4 field plot experiments to test the relationship found in the first section.

Yield Response Experiment

The relationship of nitrogen content of beardless wheatgrass, Agropyron inerme (Scrib. and Smith) Rydb., to yield was investigated in a detailed field plot experiment. The natural cover on the experimental site was an association consisting chiefly of beardless wheatgrass and sagebrush, Artemisia tridentata Nutt. The sagebrush was cleared with a heavy rotary mower cutting

${ }^{1}$ Contribution No. 106, Research Station, Canada Agriculture, Summerland, B. C. close to the ground to make it possible to use plot machinery. All previous growth of grass was cut in this operation.

Nitrogen fertilizer was applied to the plots as commercial ammonium nitrate fertilizer (33.5-0$0)$ in late November, 1958. Twelve rates of application were used $0,25,50,75,100,150,200$. $250,300,350,400$, and 450 pounds of actual nitrogen per acre. There were ten replications of each treatment. Plots were 8 by 20feet. A strip 36-inches wide by 20 -feet long was harvested through the center of each plot with a sicklebar mower. The grass was harvested at the seedset stage of maturity. The harvested grass from each plot was separated from the weeds, ovendried and weighed, and then ground in a Wiley mill and thoroughly mixed in an endover-end tumbler box. Nitrogen content of the grass was determined by the micro-kjeldahl method (A.O.A.C., 1955).

\section{Test Experiments}

Four test experiments were conducted. As before, nitrogen fertilizer was applied to the plots as commercial ammonium nitrate fertilizer. There were 4 rates of application: $0,50,150$ and 450 pounds of actual nitrogen per acre. These rates covered the same range as the yield response experiment but at greater intervals. The fertilizer was applied in late November or early December, 1959 except at Keller's where it was applied in March, 1960. There were ten replications of each treatment, except at Keller's, where only 6 replications could be fitted to the available space. However, there were
2 strips harvested in each plot at Keller's as compensation. All experiments were harvested close to the seed-set stage of maturity. The grass was separated from the other species for dry-matter determinations. Nitrogen content again was determined by the micro-kjeldahl method (A.O.A.C., 1955).

All four experiments were located on stands of grass having beardless wheatgrass as the dominant species. It was necessary to clear the sagebrush at only one site, McDougald's.

The average temperature for April, May, June and July was two degrees warmer in 1960 than in 1959. The average for 1959 was one degree lower than the 48year mean, and in 1960 it was one degree higher. Precipitation for July-June was 13.09 inches in 1958-59 and 9.36 inches in 195960 . The 42-year mean is 10.79 inches.

\section{Results}

\section{Yield Response Experiment}

The yield of beardless wheatgrass increased from 433 pounds per acre at the 0 level of nitrogen to 931 at the 450 pound level of nitrogen. However, there was little increase in yield above the 150 pound level of nitrogen which produced 862 pounds per acre.

The nitrogen content of the grass increased from 0.73 per cent at the 0 level of nitrogen application to 1.49 per cent at the 450 pound level (Table 1 ).

The "F" test for the significance of differences between means for both yield and nitrogen was significant at $\mathbf{P}=0.01$. Tukey's confidence interval, D, was calculated according to the procedure of Snedecor, 1956.

\section{Test Experiments}

The yield in the four test experiments was approximately doubled as a result of the nitrogen applications. Some burning of the plants was observed at the higher application rates, and in 
Table 1. Yield and nitrogen content of beardless wheatgrass resulting from increasing nitrogen fertilizer applications.

\begin{tabular}{ccc}
$\begin{array}{c}\text { Fertilizer } \\
\text { applied, } \\
\text { actual } \\
\text { nitrogen }\end{array}$ & $\begin{array}{c}\text { Yield } \\
\text { of grass, } \\
\text { dry matter }\end{array}$ & $\begin{array}{c}\text { Nitrogen } \\
\text { content } \\
\text { of grass }\end{array}$ \\
\hline $\begin{array}{c}\text { (pounds/ } \\
\text { acre) }\end{array}$ & $\begin{array}{c}\text { (pounds/ } \\
\text { acre) }\end{array}$ & (percent) \\
0 & $433^{1}$ & 0.731 \\
25 & 573 & 0.79 \\
50 & 685 & 0.89 \\
75 & 775 & 0.99 \\
100 & 794 & 1.10 \\
150 & 862 & 1.25 \\
200 & 768 & 1.29 \\
250 & 894 & 1.38 \\
300 & 898 & 1.37 \\
350 & 946 & 1.42 \\
400 & 885 & 1.46 \\
450 & 931 & 1.49
\end{tabular}

Tukeys confidence

interval $\quad 65 \quad 0.049$

1 "F" test significant at the $1 \%$ level.

some experiments reductions in yield occurred. The nitrogen content of the grass increased as the nitrogen applications increased (Table 2).

Effect of nitrogen content on yield

A linear regression equation was calculated for the yield and the nitrogen content of the grass from the yield response experiment. Yield was calculated as "per cent of maximum yield" by dividing the actual yield for a treatment by the maximum yield as read off a hand-drawn mean curve of the data and multiplying by 100 . This expression was further transformed to LOG (100-y) by substracting the "per cent of maximum yield" from 100 and finding its logarithm. An excellent linear relationship was found between LOG (100-y) and per cent nitrogen content of the grass (Figure 1).

A belt of confidence intervals was calculated for the regression line at 95 per cent probability by the procedure of Ezekial and Fox, 1959. This belt is plotted on Figure 1.

The data from the test experiments were also transformed as
Table 2. Yield and nitrogen content of beardless wheatgrass obtained in 4 test experiments.

\begin{tabular}{|c|c|c|c|c|c|c|}
\hline & \multicolumn{4}{|c|}{$\begin{array}{l}\text { Pounds of actual nitrogen } \\
\text { applied per acre }\end{array}$} & \multirow{2}{*}{$\begin{array}{l}\text { "F" } \\
\text { test }\end{array}$} & \multirow{2}{*}{$\begin{array}{c}\text { Tukey's } \\
\text { Confidence } \\
\text { Interval 5\% }\end{array}$} \\
\hline & 0 & 50 & 150 & 450 & & \\
\hline \multicolumn{7}{|c|}{ Yield, Ib/acre dry matter } \\
\hline Bulman & 193 & 403 & 399 & 334 & $* * 1$ & 42 \\
\hline Keller & 236 & 330 & 366 & 482 & $* *$ & 58 \\
\hline McDougald & 319 & 620 & 745 & 446 & $* *$ & 55 \\
\hline Hamilton & 352 & 658 & 589 & 312 & $* *$ & 40 \\
\hline mean & 275 & 503 & 525 & 394 & & \\
\hline \multicolumn{7}{|l|}{ Nitrogen content, \% } \\
\hline Bulman & 0.72 & 1.13 & 1.69 & 2.16 & ** & .051 \\
\hline Keller & 0.75 & 1.49 & 1.96 & 2.46 & ** & .082 \\
\hline McDougald & 0.78 & 1.05 & 1.53 & 1.78 & $* *$ & .047 \\
\hline Hamilton & 0.71 & 1.05 & 1.71 & 2.12 & $* *$ & .035 \\
\hline mean & 0.74 & 1.18 & 1.72 & 2.13 & & \\
\hline
\end{tabular}

$1^{* *}$ Significant at the $1 \%$ level.

$\operatorname{LOG}(100-y)$

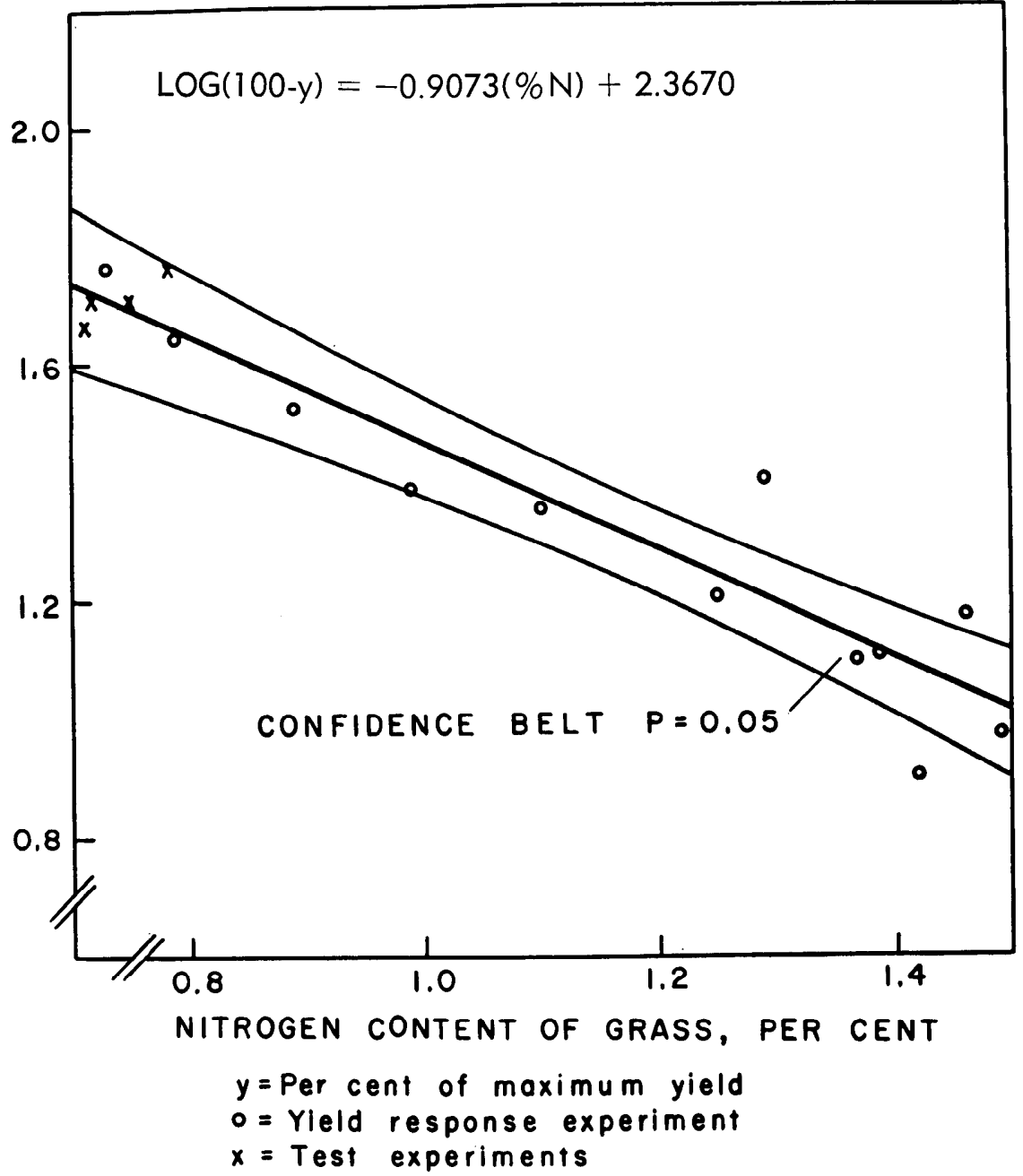

FiguRE 1. Yield expressed as percent of maximum yield and its relation to nitrogen content of grass as determined in a yield response experiment and in 4 test experiments. 
described above. One point for each of the four experiments relating nitrogen content to per cent maximum yield in the check treatment was plotted on Figure 1. All four are within the 95 per cent confidence belt.

\section{Discussion}

A relationship between the nitrogen content of range grass and the yield response to nitrogen fertilization has been found. This relationship could be useful in assessing the yield response of a site from the nitrogen analysis of the grass.

Some burning occurred from the higher rates of nitrogen application. However, it seems difficult to avoid burning entirely if rates high enough to attain maximum yields are to be used. Earlier application of the fertilizer in September might reduce the burning. The treatments in these experiments were all applied in the very late fall.

The stage of maturity at har-

${ }^{2}$ Range ecologist, Research Station, Kamloops, B. C., Canada; private communication. vest is critical, because the nitrogen content is still falling rather rapidly. According to MacLean ${ }^{2}$, the nitrogen content falls from 2.40 per cent at the leafy stage to 1.39 at flower, 1.05 at seed, 0.66 at seed-set and 0.49 at the cured stage. Therefore, care must be taken to harvest at the chosen maturity to reduce variation in maturity to a minimum.

\section{Summary}

The nitrogen content of range grass has been shown to be related to yield response to nitrogen fertilizer. A comprehensive yield response experiment on Agropyron inerme (beardless wheatgrass) gave the basic relationship between nitrogen content and yield. The linear regression equation is LOG $(100-\mathrm{y})=$ $-0.9073(\% \mathrm{~N})+2.3670$ where y is yield expressed as a per cent of the maximum yield obtained in the experiment. A series of four test experiments was used to evaluate the relationship. The yield of the check plots expressed as per cent maximum was plotted against nitrogen con- tent. The points from all four experiments were within the $95 \%$ confidence belt of the regression line. The data suggest that nitrogen analysis of range grass could be used as a measure of the fertilizer response to be expected. Grass was harvested at the seed-set stage of maturity.

\section{LITERATURE CITED}

Association of Official Agricultural Chemists. 1955. Official methods of analysis. 8th Ed. Washington, D.C.

Ezekial, M. AND K. A. Fox. 1959. Methods of correlation and regression analysis. Wiley, New York, New York.

Mader, E. L. 1957. The influence of certain fertilizer treatments on the native vegetation of Kansas prairie. Diss. Abstr. 17:209-10.

Mason, J. L. AND J. E. Miltimore. 1959. Increase in yield and protein content of native bluebunch wheatgrass from nitrogen fertilization. Can. J. Plant Sc. 39:501504.

ROGLER, G. A. AND R. J. LORENZ. 1957. Nitrogen fertilization of Northern Great Plains rangelands. Jour. Range Mangt. 10:156-160.

SNEDECOR, G. W. 1956. Statistical methods. 5th Ed. Iowa State University Press, Ames, Iowa. 